\title{
Assessing Atmospheric Instability over the Bay of Bengal during October and November Months between $2007-2018$
}

\author{
Saurav Dey Shuvo and Md. Rabiul Awal \\ Department of Meteorology, University of Dhaka, Dhaka 1000, Bangladesh \\ Manuscript received: 12 December 2020; accepted for publication: 22 April 2021
}

\begin{abstract}
An attempt has been made in this research to delineate a pattern for atmospheric instability during the months of October and November from 2007 to 2018. The results show an alarming trend of increasing instability throughout the study period. The average temperature at 2-meters height around the Bay of Bengal has changed significantly over time. Most notably, the gap between monthly average highest and monthly average lowest temperatures (at 2-meters height) is more or less increasing from 2007 to 2018 - ranging from 3.0 degrees to 11.0 degrees Celsius. Similar tendencies are observed for CAPE (Convective Available Potential Energy) as well - with the highest value of more than $3000 \mathrm{~J} / \mathrm{Kg}$. The findings of this research will help in understanding the prevailing conditions over the Bay, and also enable better preparedness for any potential severe convective activities.
\end{abstract}

Keywords: Atmospheric instability, Bay of Bengal, 2-m Air Temperature, CAPE

\section{INTRODUCTION}

Bangladesh is a deltaic country, located in South Asia - with the Himalayas to her North and the Bay of Bengal to her South. The coastal region represents an area of 47, 201 square kilometers $(\mathrm{km})$, which is about $32 \%$ of Bangladesh's total geographical coverage (Rasheed, 2008). Bangladesh is globally recognized as one of the most vulnerable countries due to natural disasters. In 2004, the United Nations Development Program (UNDP) ranked Bangladesh as the number one nation at risk for tropical cyclones and number six for floods (MoEF, 2009).

Bangladesh is regularly affected by devastating natural disasters because of its geographic location, unique natural settings, and characteristics of tropical monsoon (Paul, 2012; Haque, 1995; Elahi, 1991). The most common and catastrophic natural disasters that commonly occur include tropical cyclones, storm surges, tornados, floods, droughts, and nor-westers (Ali, 1999). The country is hit by at least one tropical cyclone each year (Haque, 1997; Mooley, 1980) that makes the coastal area more unsafe for the people living there (Murty and Neralla, 1992). The meteorological origin of tropical cyclones (TC) is owing to many complex interactions among land

\section{Corresponding author: Saurav Dey Shuvo}

Email: sauravshuvo@du.ac.bd

DOI: https://doi.org/10.3329/dujees.v9i2.55089 surface, ocean, planetary boundary layer, and convective processes (Zhang and Emanuel, 2016; Xie and Kubokawa, 1990). Several reasons; including the re-curvature phenomena of a tropical cyclone in the Bay of Bengal, shallow continental shelf, funnel shape at the head of the Bay of Bengal, almost sealevel orography of the coastal land, and high density of population; are responsible for the large impacts of tropical cyclones in Bangladesh (Murty and El-Sabh, 1992). The climatic conditions of the country are modified and regulated by these unique settings, but ultimately make the country more vulnerable to tropical cyclones (Paul and Routray, 2010; Ali, 1996). Tropical Cyclones in the past have caused massive damage to the coastal region of Bangladesh (Ramsay, 2017). The post-monsoon months are always a threat to the country as some of the most destructive tropical cyclones have formed during this season - mostly during October and November (Singh, 2007). So far in this century - Cyclone Sidr has been the most destructive post-monsoonal TC (Islam et al., 2011), which made landfall on Bangladesh's coast at around 1600 UTC on $15^{\text {th }}$ November 2007 (Paul, 2009). Although no such post-monsoon cyclones with that much intensity have not hit Bangladesh since, the probability of recurrence for such a catastrophe is not so low either (Bensi and Weaver, 2020); especially considering the situation of the Bay in October and November of recent years (Baaqeel et al., 2018).

Atmospheric Instability is always responsible for the intensification of convective activities (Chen et al., 2015; Caron et al., 2013; Craig and Gray, 1996). 
Again, an imbalance in temperature is vital for the increase in atmospheric instability (Gubenko and Rubinshtein, 2015; Marinaki et al., 2006). And, formation of tropical cyclones is closely related to an increase in atmospheric instability (Lahaye and Zeitlin, 2016; Williams and Renno, 1993). Apart from that, there is a positive correlation between the strength of tropical cyclones and the prevalence of atmospheric instability (Takemi and Yamasaki, 2020). Tropical cyclones in the Bay of Bengal, especially those formed in post-monsoon, are frequently becoming stronger (Balaguru et al., 2014; Krishna, 2009). Therefore, research on the situation regarding the recent condition of atmospheric instability over the Bay is highly necessary. Studying the evolution of atmospheric instability will provide a better understanding of the genesis of tropical cyclones, which in turn will assist in a more accurate prediction of tropical cyclones (Montgomery and Smith, 2017; Meng and Zhang, 2012). Therefore, the objective of this research is to determine the tendency of atmospheric instability over the Bay of Bengal during October and November.

\section{METHODOLOGY AND DATA USED IN THIS RESEARCH}

The study was done by recreating past scenarios with the help of forcing data through the WRF (Weather Research and Forecasting) Model (version 4.0.1). The Weather Research and Forecasting (WRF) model (version 4.0.1) has been used to derive the temperature and CAPE values for the post-monsoon season in Bangladesh. In the present research, the ARW solver of the WRF model has been used. The ARW system consists of fully compressible nonhydrostatic equations and different prognostic variables. The model's vertical coordinate is terrain following hydrostatic pressure and the horizontal grid is Arakawa C-grid. Great detail on WRF Model can be found in the works of Skamarock et al. (2008). Table 1 has all the necessary information regarding the setup of the experimental design for this research.

For this study, NCEP FNL Operational Model Global Tropospheric Analyses data have been used from NCAR's Research Data Archive (NCEP, 2000) to simulate the surface temperature and convective available potential energy over the coastal region of Bangladesh during the post-monsoon season. Global Data Assimilation System (GDAS) continuously collects observational data from the Global Telecommunications System (GTS) and other sources for analysis. Final Reanalysis (FNL) 1-degree by 1degree data collected from National Center for Environmental Prediction (NCEP) is used as initial and Lateral Boundary Conditions (LBCs), which are updated at six hours intervals.

Table 1: An Overview of the Experimental Design for this Research

\begin{tabular}{|c|c|}
\hline Properties & $\begin{array}{l}\text { Configuration for the } \\
\text { Research }\end{array}$ \\
\hline Dynamics & Non-hydrostatic \\
\hline Microphysics & Ferrier (new Eta) scheme \\
\hline Radiation scheme & $\begin{array}{l}\text { Dudhia for short-wave } \\
\text { radiation / RRTMG for } \\
\text { long-wave }\end{array}$ \\
\hline Surface layer & Noah-LSM scheme \\
\hline $\begin{array}{l}\text { Cumulus parameterization } \\
\text { schemes }\end{array}$ & Kain-Fritsch scheme \\
\hline PBL parameterization & Yonsei University scheme \\
\hline Number of domains & 01 (one) \\
\hline Central points of the domain & $\begin{array}{l}\text { Central Latitude: } 18^{\circ} \mathrm{N} ; \\
\text { Central Longitude: } 91^{\circ} \mathrm{E}\end{array}$ \\
\hline Horizontal grid distance & 18 kilometers \\
\hline Integration time step & 90 seconds \\
\hline Number of grid points & $\begin{array}{l}\text { X-direction: } 54 \text { points; Y- } \\
\text { direction: } 108 \text { points }\end{array}$ \\
\hline Map projection & Mercator \\
\hline Horizontal grid distribution & Arakawa C-grid \\
\hline Vertical co-ordinate & $\begin{array}{c}\text { Terrain-following } \\
\text { hydrostatic-pressure co- } \\
\text { ordinate }(33 \text { sigma levels } \\
\text { up to } 100 \mathrm{hPa})\end{array}$ \\
\hline Time integration & $3^{\text {rd }}$ order Runge-Kutta \\
\hline Spatial differencing scheme & $\begin{array}{c}6^{\text {th }} \text { order centered } \\
\text { differencing }\end{array}$ \\
\hline Initial conditions & $\begin{array}{l}\text { Three-dimensional real- } \\
\text { data }\left(\mathrm{FNL}: 1^{\circ} \times 1^{\circ}\right)\end{array}$ \\
\hline Lateral boundary condition & $\begin{array}{c}\text { Specified options for real- } \\
\text { data }\end{array}$ \\
\hline Top boundary condition & $\begin{array}{c}\text { Gravity wave absorbing } \\
\text { (diffusion or Rayleigh } \\
\text { damping) }\end{array}$ \\
\hline Bottom boundary condition & Physical or free-slip \\
\hline Diffusion and Damping & $\begin{array}{l}\text { Simple Diffusion with No } \\
\text { Damping }\end{array}$ \\
\hline
\end{tabular}

The WRF model has been configured in a singlenested domain (Figure 1) of $18 \mathrm{~km}$ horizontal grid spacing with $54 \times 108$ grids in the east-west and northsouth directions and 33 vertical levels. In this research, the Ferrier (new Eta) microphysics scheme coupling with the Kain-Fritsch cumulus parameterization scheme has been used. 
The model has been integrated by using initial and LBCs from NCEP-FNL analyses data (Dutra et al., 2017) at six hourly intervals. The model has been simulated continuously for 31 days to get a long-range observational scenario starting with the initial conditions for 0000 UTC of $1^{\text {st }}$ October and continuing up to 1800 UTC of $31^{\text {st }}$ October; for the years of 2007 to 2018 . With a similar mechanism and experimental setup, simulated values of November (for the aforementioned 12 years) have also been obtained. The instability conditions during October November of 2007 have been given more importance in the analyses, due to the intensity and sheer destruction caused by Cyclone Sidr (Haque and Jahan, 2016; Nadiruzzaman and Wrathall, 2015; Paul, 2010) during November of 2007. The succeeding 11 years after 2007 (2008 to 2018) have been analyzed - to discern a trend of atmospheric instability over the Bay of Bengal - to fulfill the objectives of this research.

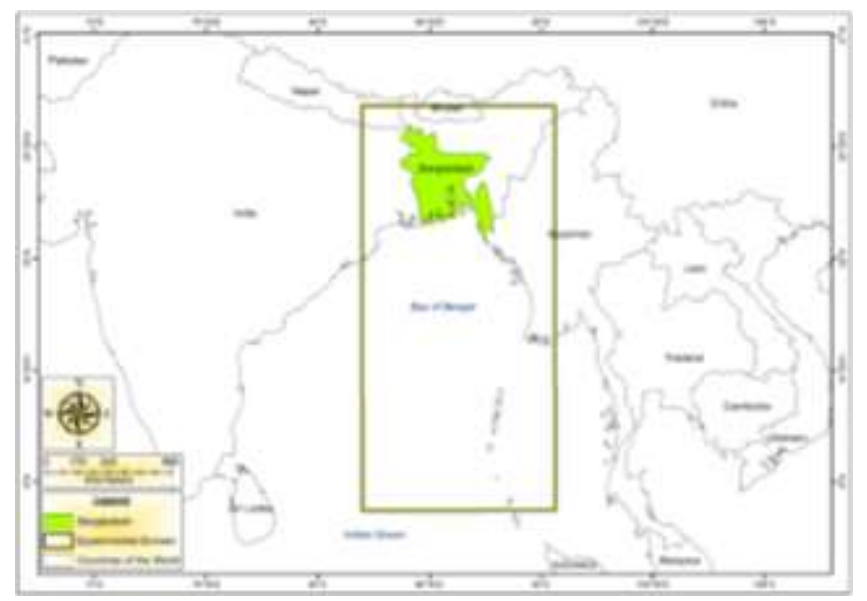

Figure 1: Experimental Domain for Simulations with WRF Model in this Research. The experimental domain has been drawn with WRF-Hydro GIS (Geographic Information System) pre-processing toolkit (downloaded from https://ral.ucar.edu/projects/wrf_hydro/pre-processing-tools) integrated with ArcGIS Software (version 10.6)

Two (02) parameters were chosen for analysis, which are - Air Temperature at 2-meters height and Convective Available Potential Energy (CAPE). The 2-m air temperature has been essential in understanding the near-surface temperature situations (Baker, 1975), and hence has been widely used by operational meteorologists (Rayner et al., 2003; Whitaker and Hamill, 2002). For avoiding redundancy, this parameter is cited as 'Surface Temperature' in the following sections. The highest average temperature and lowest average temperature values for 24 months (October and November for 12 consecutive years) have been calculated from simulated results. Again, CAPE is an essential atmospheric instability index for studying tropical cyclones (Molinari et al., 2012) and requires the temperature values for calculation (Moncrieff and Miller, 1976). Monthly averaged CAPE values have been calculated and used in this research. Also, it should be noted that - all the averages used in this research are temporal averages, not spatial averages (Moody et al., 2008). Monthly maximum and minimum CAPE values, which were also analyzed, were also identified from the simulations.

Records of tropical cyclones over the Bay of Bengal have been accessed from the portal of RSMC (https://rsmcnewdelhi.imd.gov.in/). RSMC or Regional Specialized Meteorological Centre has data available from the $19^{\text {th }}$ century onwards (Mohapatra and Vijay Kumar, 2017). But for this research, data for 2007 to 2018 have been collected. Also, the data for Severe Cyclonic Storms - SCS (maximum sustained surface wind speed of 48 to 63 knots) and above are being used in this research.
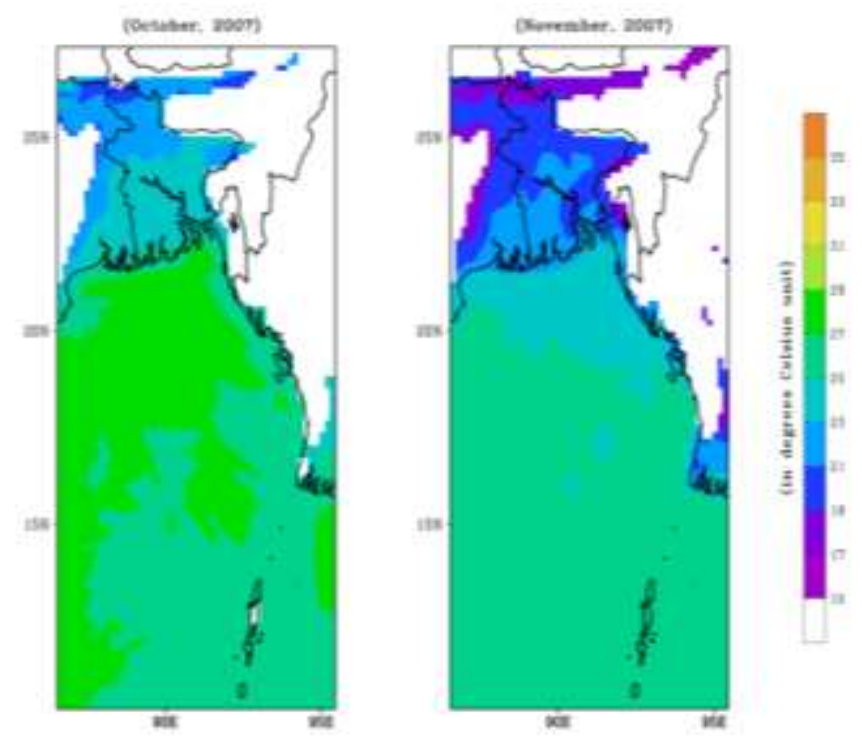

Figure 2: Distributions for Monthly Average Surface Temperature During October and November of 2007

\section{DISTRIBUTION OF SURFACE TEMPERATURE}

The monthly average distribution of surface temperature for 2007 has been illustrated in Figure 2. The temperature in October ranged between 25 to 29 degrees Celsius, but a major portion of the Bay remained within 27 to 29 degrees Celsius. The Bay 
became cooler during November of 2007. Most portions remained within 25 to 27 degrees Celsius. The temperature further decreased to the north, gaining a lowest value of 21 degrees near the coastal regions of Bangladesh.

The distributions for 2008 to 2018 are listed in Table 2a. From 2008 onwards, a rise in monthly highest average surface temperature value (from the value of 2007) was found. The average highest temperature in October remained between 31 to 33 degrees Celsius $\left({ }^{\circ} \mathrm{C}\right)$ from 2008 to 2015; after which it went below $30^{\circ} \mathrm{C}$. For the distributions of highest average temperature values in November, the range was from 30 to $33^{\circ} \mathrm{C}$. Similar to the distributions of highest average maximum values in October, the values for November were also found to be less than $30^{\circ} \mathrm{C}$ from 2016 to 2018 . So, 8 values of monthly average highest temperature for October were greater than the value for 2007; 1 was equal and the remaining 2 were lower.

The lowest average temperature for October values had multiple peaks of increasing and decreasing values within its distribution. A decrease in values (from the values for 2007) of the lowest average temperature was observed for 2008 and 2009. After that, from 2010 onwards, an increasing trend continued up to 2013. Again, the values showed a decrease in both 2014 and 2015. After an increase in 2016, the lowest average monthly temperature dipped to $21^{\circ} \mathrm{C}$. So, only 4 values of monthly average lowest temperature for October were greater than that of 2007; 1 was equal and 6 values were lower.

The monthly highest average temperature values for November showed similar tendencies to the distributions of October. The values increased from 2008 onwards - ranging from 30 to $33^{\circ} \mathrm{C}$. From 2016 onwards, there was a decrease. But to the contrary of the distribution for October, the values remained equal or more than the values for November of 2007. Therefore, no values of the highest average monthly temperature from 2008 to 2018 were less than that of November 2007; 10 were greater and only 1 was equal.

The monthly lowest average temperature value for November-2007 was $20^{\circ} \mathrm{C}$. From 2008 onwards, it showed an increase that continued up to 2013. Then there was a slight decrease, followed by increased and decreased values in every alternate year (except for
November of 2015 and 2016). Therefore, 2 lower values (in comparison to the value for November 2007) were found for the lowest monthly temperature value for the distribution of November; 1 equal and 8 greater values were observed.

\section{DISTRIBUTION OF CAPE}

The 2007 distributions of monthly average CAPE for October and November are given in Figure 3. During October, most parts of the Bay had CAPE values higher than $1700 \mathrm{~J} / \mathrm{Kg}$ (Joules per Kilogram). Lower CAPE values (less than $500 \mathrm{~J} / \mathrm{Kg}$ ) were observed around the coastal regions. The monthly average CAPE during November ranged between 500 to $900 \mathrm{~J} / \mathrm{Kg}$ within a major area of the Bay, while the remaining areas had an average CAPE of less than $500 \mathrm{~J} / \mathrm{Kg}$.

The monthly maximum and minimum CAPE values (Table $2 b$ ) have been picked out for gaining a much better insight into the conditions over the Bay. The maximum CAPE was $3000 \mathrm{~J} / \mathrm{Kg}$ in October 2007. This value remained to the highest up to 2015. A maximum CAPE of $3200 \mathrm{~J} / \mathrm{Kg}$ was found during October of 2016. In between 2007 and 2016, a value of $2900 \mathrm{~J} / \mathrm{Kg}$ was also found during October of 2013. The final two years of the distribution had a maximum CAPE of equal and considerably less than $3000 \mathrm{~J} / \mathrm{Kg}$, which was the obtained value for October of 2007.
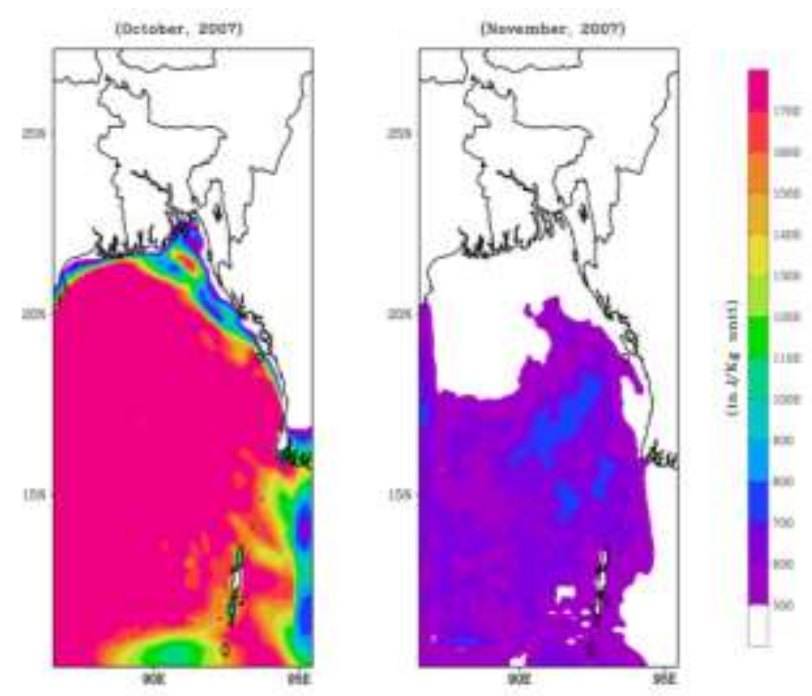

Figure 3: Distributions for Monthly Average CAPE during October and November of 2007

The monthly minimum CAPE values for October had a different distribution. This distribution showed 
multiple peaks of increase and decrease. But the most notable values were found for Octobers of 2013 and 2017 - whereby the values were found to be 1400 $\mathrm{J} / \mathrm{Kg}$ and $1700 \mathrm{~J} / \mathrm{Kg}$. Both values were greater than the monthly maximum CAPE value for October of 2009 $(1300 \mathrm{~J} / \mathrm{Kg})$. Other values were lower or equal to 700 $\mathrm{J} / \mathrm{Kg}$.

The monthly maximum CAPE value for November also showed multiple increases and decreases when compared with the value for November of $2007(1400 \mathrm{~J} / \mathrm{Kg})$. The values mostly remained within $1800 \mathrm{~J} / \mathrm{Kg}$. However, maximum CAPE values of more than $2000 \mathrm{~J} / \mathrm{Kg}$ were found for the November months of 2010, 2013, and 2016. A longer increasing pattern for maximum CAPE values was observed from 2013 to 2017 (in comparison with 2007). But, the value for 2018 became much lower than the preceding values.

The lowest CAPE values for November showed an increasing trend from 2008 to 2015. The lowest minimum CAPE value for November-2013 (1200 $\mathrm{J} / \mathrm{Kg}$ ) was higher than the maximum CAPE values for November 2009 and 2018. But recent years found a slightly decreasing trend in minimum CAPE value for the distributions of November.

\section{DISCUSSING MAJOR FINDINGS}

The distributions of both surface temperature and CAPE are being described in previous sections. From both distributions, it is obvious that there are increases and decreases in both parameters during recent years. But, interestingly the extent of this change - be it increasing or decreasing - is neither equal nor symmetric. Tables $2 \mathrm{a}$ and $2 \mathrm{~b}$ have all the records from the simulations for this research. Also, the frequency data for tropical cyclones (SCS and above) formed at the Bay of Bengal during the study period have been listed in Table 2c.

Table 2: Distributions of Maximum and Minimum - (a) Surface Temperature; and (b) CAPE Values for the Experiments in this Research. (c) Frequency Data for Tropical Cyclones (SCS and above) Formed over the Bay of Bengal from October and November of 2007 to 2018

\begin{tabular}{|c|c|c|c|}
\hline Time & Highest Average Value & Lowest Average Value & Difference \\
\hline \multicolumn{4}{|c|}{ (a) distribution of Surface Temperature (in degrees Celsius unit) } \\
\hline October-2007 & 28 & 25 & 3 \\
\hline October-2008 & 32 & 24 & 8 \\
\hline October-2009 & 32 & 24 & 8 \\
\hline October-2010 & 33 & 25 & 8 \\
\hline October-2011 & 33 & 27 & 6 \\
\hline October-2012 & 32 & 29 & 3 \\
\hline October-2013 & 32 & 30 & 2 \\
\hline October-2014 & 32 & 24 & 8 \\
\hline October-2015 & 31 & 24 & 7 \\
\hline October-2016 & 28 & 26 & 2 \\
\hline October-2017 & 27 & 23 & 4 \\
\hline October-2018 & 27 & 21 & 6 \\
\hline November-2007 & 26 & 20 & 6 \\
\hline November-2008 & 30 & 21 & 9 \\
\hline November-2009 & 31 & 25 & 6 \\
\hline November-2010 & 30 & 28 & 2 \\
\hline November-2011 & 31 & 22 & 9 \\
\hline November-2012 & 31 & 27 & 4 \\
\hline November-2013 & 33 & 26 & 7 \\
\hline November-2014 & 30 & 19 & 11 \\
\hline November-2015 & 30 & 20 & 10 \\
\hline November-2016 & 27 & 23 & 4 \\
\hline November-2017 & 26 & 18 & 8 \\
\hline November-2018 & 28 & 22 & 6 \\
\hline
\end{tabular}




\begin{tabular}{|c|c|c|c|}
\hline \multicolumn{4}{|c|}{ (b) distribution of Convective Available Potential Energy (in $\mathrm{J} / \mathrm{Kg}$ unit) } \\
\hline Time & Maximum Value & Minimum Value & Difference \\
\hline October-2007 & 3000 & 550 & 2450 \\
\hline October-2008 & 1700 & 500 & 1200 \\
\hline October-2009 & 1300 & 550 & 750 \\
\hline October-2010 & 2200 & 650 & 1550 \\
\hline October-2011 & 1900 & 550 & 1350 \\
\hline October-2012 & 1800 & 450 & 1350 \\
\hline October-2013 & 2900 & 1400 & 1500 \\
\hline October-2014 & 2000 & 700 & 1300 \\
\hline October-2015 & 1900 & 700 & 1200 \\
\hline October-2016 & 3200 & 600 & 2600 \\
\hline October-2017 & 3000 & 1700 & 1300 \\
\hline October-2018 & 2100 & 300 & 1800 \\
\hline November-2007 & 1400 & 850 & 550 \\
\hline November-2008 & 1200 & 400 & 800 \\
\hline November-2009 & 1100 & 450 & 650 \\
\hline November-2010 & 2200 & 600 & 1600 \\
\hline November-2011 & 1500 & 700 & 800 \\
\hline November-2012 & 1350 & 650 & 700 \\
\hline November-2013 & 2500 & 1200 & 1300 \\
\hline November-2014 & 1800 & 850 & 950 \\
\hline November-2015 & 1500 & 700 & 800 \\
\hline November-2016 & 2200 & 300 & 1900 \\
\hline November-2017 & 1600 & 400 & 1200 \\
\hline November-2018 & 1050 & 300 & 750 \\
\hline \multicolumn{4}{|c|}{ (c) number of tropical cyclones formed over the Bay of Bengal } \\
\hline Year & Total Number of TCs & \begin{tabular}{l|r} 
er & Total N
\end{tabular} & during November \\
\hline 2007 & 0 & & \\
\hline 2008 & 0 & & \\
\hline 2009 & 0 & & \\
\hline 2010 & 1 & & \\
\hline 2011 & 0 & & \\
\hline 2012 & 0 & & \\
\hline 2013 & 1 & & \\
\hline 2014 & 1 & & \\
\hline 2015 & 0 & & \\
\hline 2016 & 0 & & \\
\hline 2017 & 0 & & \\
\hline 2018 & 1 & & \\
\hline
\end{tabular}

The most notable thing is the difference in monthly highest average temperature and monthly lowest average temperature values. Since 2008, the gap has remained mostly above $6^{\circ} \mathrm{C}$ apart from the values for October-2012, 2013, 2016, 2017; and November-2010, 2012, 2016. The difference remained to be more than $10^{\circ} \mathrm{C}$ during two consecutive Novembers of 2014 and 2015. This gap is always increasing with time, and if this trend continues then it may cause a significant rise in atmospheric instability over the Bay (Chen et al., 2020; Holley et al., 2014; Gettelman et al., 2002).
A steady rise in atmospheric instability has been observed over the Bay throughout the study period. The change in CAPE did not maintain any pattern, similar to that of surface temperature. But a conspicuous change can be easily understood from the distributions of maximum and minimum CAPE values for October. The difference between the maximum and minimum CAPE values was found to be less than $1200 \mathrm{~J} / \mathrm{Kg}$ only once - during October of 2009. And in recent years, the gap between monthly maximum and minimum CAPE values has shown a clear 
increase. With these analyses, the frequency data for tropical cyclones over the Bay of Bengal provide a very clear scenario. Throughout the study period of 12 years (2007 to 2018), only 03 years have recorded tropical cyclones in consecutive months of October and November - 2010, 2013, and 2018. And during both years of 2017 and 2018, November has experienced tropical cyclones over the Bay. Also, 2013 has seen the highest number of tropical cyclones (3) among the years studied in this research. It should be noted that -2013 saw considerably high values of both maximum and minimum CAPE. A subtle increase in the number of TCs since 2013 can be easily envisaged.

There are implications of an increasing atmospheric instability to the intensification of tropical cyclones (Lee and Frisius, 2018; Seeley and Romps, 2015). The analyses and data in this research can delineate a pattern of increasing atmospheric instability and rising numbers of TCs. This trend of an increasing number of TCs may continue in the future as well if the atmospheric instability is continuing to be augmented.

\section{CONCLUSIONS}

In this research, the atmospheric instability over the Bay of Bengal during the October and November months has been assessed for a study period of 12 years - from 2007 to 2018. The objective was to seek a pattern of atmospheric instability - be it increasing or decreasing. The study reveals that there is a change in temperature activities over the Bay during these 12 years. The difference between the monthly average highest temperature and lowest temperatures is increasing over time. Along with that, the CAPE values are also increasing. And, there is a rise in the frequency of TCs also. So, all these comprehend a worrying scenario for Bangladesh - where the country may frequently experience more intense tropical cyclones in the future.

\section{REFERENCES}

Caron, L. P., Jones, C. G., Vaillancourt, P. A., \& Winger, K. (2013). On the relationship between cloud-radiation interaction, atmospheric stability and Atlantic tropical cyclones in a variable-resolution climate model. Climate Dynamics, 40(5-6), 1257-1269. https://doi. org /10.1007/s00382-012-1311-6.
Ali, A. (1996). Vulnerability of Bangladesh to climate change and sea level rise through tropical cyclones and storm surges. Water, Air, \& Soil Pollution, 92(12):171-179.

Ali, A. (1999). Climate change impacts and adaptation assessment in Bangladesh. Climate Research, 12(2-3): 109-116.

Baaqeel, A. H., Daghreri, Y. A., Hajlaa, S. A. B., \& Al-Yami, H. H. (2018). Estimating the frequency, magnitude and recurrence of extreme cyclones in Northern Indian Ocean. Int J Sci Techn Res Eng, 3, 7-17.

Baker, D. G. (1975). Effect of observation time on mean temperature estimation. Journal of Applied Meteorology and Climatology, 14(4), 471-476. https://doi.org/10. 1175/1520 0450(1975)014<0471: EOOTOM>2.0.CO;2

Balaguru, K., Taraphdar, S., Leung, L. R., \& Foltz, G. R. (2014). Increase in the intensity of postmonsoon Bay of Bengal tropical cyclones. Geophysical Research Letters, 41(10), 3594-3601. https://doi.org/10.1002/ 2014 GL060197.

Bensi, M., \& Weaver, T. (2020). Evaluation of tropical cyclone recurrence rate: factors contributing to epistemic uncertainty. Natural Hazards, 103(3), 30113041. https://doi.org/10.1007/s11069-020-04117-2.

Chen, J., Dai, A., Zhang, Y., \& Rasmussen, K. L. (2020). Changes in Convective Available Potential Energy and Convective Inhibition under Global Warming. Journal of Climate, 33(6), 2025-2050. https://doi.org/10.1175/ JCLI-D-19-0461.1.

Chen, S., Lu, Y., Li, W., \& Wen, Z. (2015). Identification and analysis of high-frequency oscillations in the eyewalls of tropical cyclones. Advances in Atmospheric Sciences, 32(5), 624-634. https://doi.org/10.1007/ s00376-014-4063-x.

Craig, G. C., \& Gray, S. L. (1996). CISK or WISHE as the Mechanism for Tropical Cyclone Intensification. Journal of Atmospheric Sciences, 53(23), 3528-3540.

Dutra, L. M. M., da Rocha, R. P., Lee, R. W., Peres, J. R. R., \& de Camargo, R. (2017). Structure and evolution of subtropical cyclone Anita as evaluated by heat and vorticity budgets. Quarterly Journal of the Royal Meteorological Society, 143(704), 1539-1553. doi:10.1002/qj.3024.

Elahi, K.M. (1991). Impacts of riverbank erosion and flood in Bangladesh: an introduction. In Elahi, K.M., Ahmed, K.S. \& Mafizuddin, M. (eds.). Riverbank Erosion, Flood and Population Displacement in Bangladesh. Riverbank Erosion Impact Study (REIS), Jahangirnagar University, Dhaka. 
Gettelman, A., Seidel, D. J., Wheeler, M. C., \& Ross, R. J. (2002). Multidecadal trends in tropical convective available potential energy. Journal of Geophysical Research: Atmospheres, 107(D21), ACL-17. https://doi.org/10.1029/2001JD001082.

Gubenko, I. M., \& Rubinshtein, K. G. (2015). Analysis of the results of thunderstorm forecasting based on atmospheric instability indices using the WRF-ARW numerical model data. Russian Meteorology and Hydrology, 40(1), 16-24. https://doi.org/10.3103/S1068373915010033.

Haque, A., \& Jahan, S. (2016). Regional impact of cyclone sidr in Bangladesh: A multi-sector analysis. International Journal of Disaster Risk Science, 7(3),312-327. https://doi.org/10.1007/s13753-016-0100-y.

Haque, C.E. (1995). Climatic hazards warning process in Bangladesh: experience of, and lessons from, the 1991 April cyclone. Environmental Management, 19(5):719734.

Haque, C.E. (1997). Atmospheric hazards preparedness in Bangladesh: A study of warning, adjustments and recovery from the April 1991 cyclone. Natural Hazards, 16(2-3): 181-202.

Holley, D. M., Dorling, S. R., Steele, C. J., \& Earl, N. (2014). A climatology of convective available potential energy in Great Britain. International Journal of Climatology, 34(14), 3811-3824. https://doi.org/10.1002/joc.3976

Islam, A. S., Bala, S. K., Hussain, M. A., Hossain, M. A., \& Rahman, M. M. (2011). Performance of coastal structures during Cyclone Sidr. Natural Hazards Review, 12(3), 111-116. doi:10.1061/(asce)nh.15276996.0000031

Krishna, K. M. (2009). Intensifying tropical cyclones over the North Indian Ocean during summer monsoon-Global warming. Global and Planetary Change, 65(1-2), 12-16. https://doi.org/10.1016/j.gloplacha.2008.10. 007

Lahaye, N., \& Zeitlin, V. (2016). Understanding Instabilities of Tropical Cyclones and Their Evolution with a Moist Convective Rotating Shallow-Water Model, Journal of the Atmospheric Sciences, 73(2), 505-523. https://doi.org/10.1175/JAS-D-15-0115.1

Lee, M., \& Frisius, T. (2018). On the role of convective available potential energy (CAPE) in tropical cyclone intensification. Tellus A: Dynamic Meteorology and Oceanography, 70(1), 1-18. https://doi.org/10.1080/16000870.2018.1433433

Marinaki, A., Spiliotopoulos, M., \& Michalopoulou, H. (2006). Evaluation of atmospheric instability indices in Greece. Advances in Geosciences, 7, 131-135. https://doi.org/10.5194/adgeo-7-131-2006, 2006.
Meng, Z., \& Zhang, Y. (2012). On the Squall Lines Preceding Landfalling Tropical Cyclones in China. Monthly Weather Review, 140, 445-470. https://doi.org/10.1175/MWR-D-10-05080.1

MoEF (2009). Bangladesh Climate Change Strategy and Action Plan 2009. Ministry of Environment and Forests, Government of the People's Republic of Bangladesh, Dhaka, Bangladesh.

Mohapatra, M., \& Vijay Kumar, V. (2017). Interannual variation of tropical cyclone energy metrics over North Indian Ocean. Climate Dynamics, 48(5-6), 1431-1445. https://doi.org/10.1007/s00382-016-3150-3

Molinari, J., Romps, D. M., Vollaro, D., \& Nguyen, L. (2012). CAPE in tropical cyclones. Journal of the Atmospheric Sciences, 69(8), 2452-2463. https://doi.org/10.1175/JAS-D-11-0254.1

Moncrieff, M.W. and Miller, M.J. (1976), The dynamics and simulation of tropical cumulonimbus and squall lines. Q.J.R. Meteorol. Soc., 102: 373-394. https://doi.org/10. 1002/qj.49710243208

Montgomery, M. T., \& Smith, R. K. (2017). Recent Developments in the Fluid Dynamics of Tropical Cyclones. Annual Review of Fluid Mechanics, 49, 541574.https://doi.org/10.1146/annurev-fluid 010816 060022

Moody, E. G., King, M. D., Schaaf, C. B., \& Platnick, S. (2008). MODIS-Derived Spatially Complete Surface Albedo Products: Spatial and Temporal Pixel Distribution and Zonal Averages, Journal of Applied Meteorology and Climatology, 47(11), 2879-2894. https://doi.org/10.1175/2008JAMC1795.1

Mooley, D.A. (1980). Severe cyclonic storms in the Bay of Bengal, 1877-1977. Monthly Weather Review, 108(10): 1647-1655.

Murty, T.S. \& El-Sabh, M. (1992). Mitigating the effects of storm surges generated by tropical cyclones - a proposal. Natural Hazards, 6(3): 251-273.

Murty, T.S. \& Neralla, V. R. (1992). On the recurvature of tropical cyclones and the storm surge problem in Bangladesh. Natural Hazards, 6(3): 275-279.

Nadiruzzaman, M., \& Wrathall, D. (2015). Participatory exclusion-Cyclone Sidr and its aftermath. Geoforum, 64, 196-204. https://doi.org/10.1016/j.geoforum.2015.06.026

National Centers for Environmental Prediction. (2000). NCEP FNL Operational Model Global Tropospheric Analyses, continuing from July 1999. Research Data Archive at the National Center for Atmospheric Research, Computational and Information 
Systems Laboratory. https://doi.org/10. 5065/ D6M0 43C6.Accessed 15 th March 2019.

Paul S.K and Routray J.K. (2010). Household response to cyclone and induced surge in Coastal Bangladesh: coping strategies and explanatory variables. Natural Hazards, 57(2): 477-499.

Paul, B. K. (2009). Why relatively fewer people died? The case of Bangladesh's Cyclone Sidr. Natural Hazards, 50(2), 289-304. https://doi.org/10.1007/ s11069-008-9340-5

Paul, B. K. (2010). Human injuries caused by Bangladesh's cyclone Sidr: an empirical study. Natural hazards, 54(2), 483-495. https://doi.org/10.1007/ s11069-009-9480-2

Paul, S.K. (2012). Vulnerability to tropical cyclone in the southern Bangladesh: impacts and determinants. Oriental Geographer, 53(1-2): 19-40.

Ramsay, H. (2017). The Global Climatology of Tropical Cyclones Tropical Cyclones. In Oxford Research Encyclopedias (pp. 1-35). https://doi.org/https://doi.org/10.1093/acrefore/978019 9389407.013.79

Rasheed, K. B. S. (2008). Bangladesh: Resource and Environmental Profile. A H Development Publishing House. Dhaka, Bangladesh.

Rayner, N. A. A., Parker, D. E., Horton, E. B., Folland, C. K., Alexander, L. V., Rowell, D. P., Kent, E. C., \& Kaplan, A. (2003). Global analyses of sea surface temperature, sea ice, and night marine air temperature since the late nineteenth century. Journal of Geophysical Research: Atmospheres, 108(D14). doi:10.1029/2002JD002670.
Seeley, J. T., \& Romps, D. M. (2015). Why does tropical convective available potential energy (CAPE) increase with warming? Geophysical Research Letters, 42(23), 10-429. https://doi.org/10.1002/2015GL066199

Singh, O. P. (2007). Long-term trends in the frequency of severe cyclones of Bay of Bengal: Observations and simulations. Mausam, 58(1), 59-66.

Skamarock, W.C., Klemp, J.B., Dudhia, J., Gill, D.O., Barker, D.M., Duda, M., Huang, X-Y, Wang, W. \& Powers, J.G. (2008). A description of the advanced research WRF version 3. NCAR technical note.

Takemi, T., \& Yamasaki, S. (2020). Sensitivity of the intensity and structure of tropical cyclones to tropospheric stability conditions. Atmosphere, 11(4), 411. https://doi.org/10.3390/atmos11040411

Whitaker, J. S., \& Hamill, T. M. (2002). Ensemble Data Assimilation without Perturbed Observations, Monthly Weather Review, 130(7), 1913-1924. https://doi.org/10.1175/15200493(2002)130<1913:EDAWPO>2.0.CO;2

Williams, E., \& Renno, N. (1993). An Analysis of the Conditional Instability of the Tropical Atmosphere, Monthly Weather Review, 121(1), 21-36. https://doi.org/10.1175/15200493(1993)121<0021:AAOTCI>2.0.CO;2

Xie, P., \& Kubokawa, A. (1990). On the Wave-CISK in the Presence of a Frictional Boundary Layer. Journal of Meteorological Society of Japan, 68(6), 651-657.

Zhang, F., \& Emanuel, K. (2016). On the role of surface fluxes and WISHE in tropical cyclone intensification. Journal of the Atmospheric Sciences, 73(5), 20112019. https://doi.org/10.1175/JAS-D-16-0011.1. 
